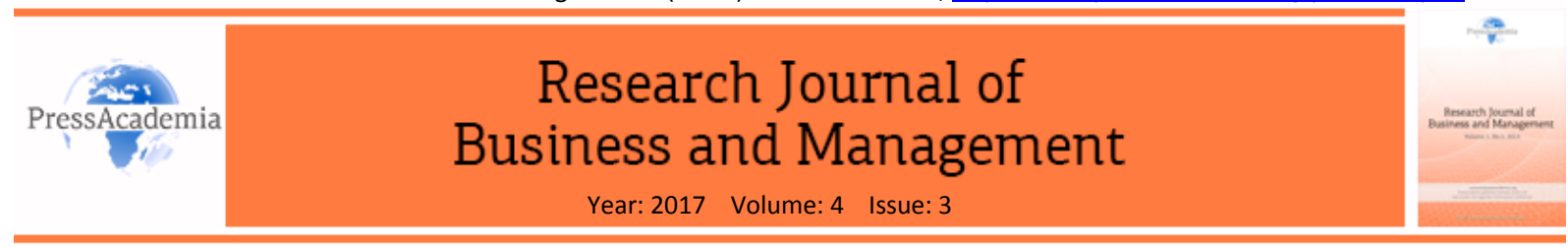

\title{
COULD INDEPENDENT BOARD, BOARD MEETING, AUDIT COMMITTEE, AND RISK COMMITTEE IMPROVE THE ASSET QUALITY AND OPERATIONAL PERFORMANCE? A STUDY OF LISTED BANKS IN INDONESIA
}

\author{
DOI: 10.17261/Pressacademia.2017.702 \\ RJBM-V.4-ISS.3-2017(1)-p.247-254
}

Te-Kuang Chou ${ }^{1}$, Agung Dharmawan Buchdadi ${ }^{2}$

${ }^{1}$ Southern Taiwan University of Science and Technology, 1, Nantai St, Tainan, Taiwan. dkchou@mail.stust.edu.tw

${ }^{2}$ State University of Jakarta, Jl Rawamangun Muka, Jakarta, Indonesia. agungdharmawan@feunj.ac.id

\section{To cite this document}

Chou, Te-Kuang and A.D. Buchdadi, (2017). Could independent board, board meeting, audit committee, and risk committee improve the asset quality and operational performance? a study of listed banks in Indonesia. Research Journal of Business and Management(RJBM), V.4, Iss.3, p.247-254.

Permemant link to this document:http://doi.org/10.17261/Pressacademia.2017.702

Copyright: Published by PressAcademia and limited licenced re-use rights only.

\begin{abstract}
Purpose - This study examines the impact of independent board of directors, board meeting, audit committee, and risk committee on bank practise in Indonesia.

Methodology - Asset quality is measured by non-performing loans (NPL), and operational performance is measured by operational expense ratio (BOPO). While, as independent variables we used some good corporate governance variables including independent board (IB), the annual board meeting (BM), the percentage of annual board of director meeting attendance, the annual board-executive meeting (BEM), the percentage of annual board-executive meeting attendance, Audit Committee (AC), Audit Committee Meeting (ACM), the percentage of annual audit committee meeting attendance, Risk Committee (RC), Risk Committee Meeting (RCM), and the percentage of annual risk committee meeting attendance. The data are listed banks in Indonesian Capital Market during 2013-2015 using unbalanced panel data two stage least square (2SLS) regression.

Findings- The findings reveal that independent board will improve the prudence principal of the bank. While the board of directors meeting will enhance the operational performance of the bank.In addition, the number of the audit committee will make better operational performance, while the number of meeting will improve the non-performing loan.

Conclusion- Regarding these results the central bank and also the other stakeholders could maintain the role of the independent board of directors as well as the number of high quality annual meeting of the board. In addition, this study also reveals the role of the audit committee in banking business. This study supports the agency theory that monitoring activity will make the firm better performance.
\end{abstract}

Keywords: Audit committee, independent board, risk committee,non-performing loan, operational expense ratio. JEL Codes: G21, G30, G34

\section{INTRODUCTION}

Many academicians are interested to conduct study examining the impact of good corporate governance on the firm performance (Mashayekhi and Bazaz, 2008; Munisi and Randoy, 2013; Al-Najjar, 2014; Zagorchev and Gao, 2015; Balachandran and Faff, 2015; Subramanian, 2015; Abdallah and Ismail, 2016; Akbar et al., 2016; Ararat, Black and Yurtoglu, 2016; Chauhan, Lakshmi and Dey, 2016; Prommin et al., 2016). Good corporate governance could reduce the agency cost and make better protection for shareholder againts uncertainty in the future (Balachandran and Faff, 2015). Moreover, some studies try to find the attributes regarding the corporate governance in developing countries. The differences condition in political, economic, technological and cultural on each developing country could make a unique corporate governance behaviour in compare to developed country (Mulili and Wong, 2011). This one of the reason why examining good corporate governance impact on firm performance is still attracted among the scholar.

The recent research suggests more research good corporate governance in the banking sector (Claessens and Yurtoglu, 2013) in order to develop corporate governance in the others sector. Bank provides an important role as the agent of another stakeholder. Then, enhancing the corporate governance of banks may be effective in improving overall 
governance. Moreover, banking sector as the main sources of a financial intermediary is important for the long run economic development in ASEAN regional countries (Pradhan et al., 2014). Yet, the governance mechanism in the banking industry is different with other industry. In practise, it will more focus on ownership structure and governance, and internal governance mechanisms (Tan, 2014).

In Indonesia, the corporate governance regulation in banking industry starts in 2006. The regulation is updated in 2013 (Sentral, 2013). According to the regulation that a bank has to hire at least $50 \%$ of the independent board of director, make the bodies under the board of directors, i.e.audit committee, risk monitoring committee, and the remuneration and nomination committee. The bank has to release annual report including reporting the number of meeting and attendance report of the board of directors(Indonesia, 2006). Then, as long as we know only few study aims to examine the impact of good corporate governance in banking in Indonesia. One study findings reveal that return on equity (ROE) and Size have a significant negative relationship to GCG index. While, return on asset(ROA) and fixed asset variables have a significant positive relationship to GCG index(Markonah, Cahaya and Riwayati, 2016). Meanwhile, one study mentioned that the board of directors have a negatif and insignificant effect on return on assets (ROA). Independent board has a positif and insignificant effect on return on assets (ROA). The corporate governance and leverage have simultaneously effect on return on assets (ROA) of the banking company (Hamidah, Purwati and Mardiyati, 2013). In order to extend the previous study examining the good corporate governance (GCG) in the banking sector in Indonesia, we will explore the impact of GCG on asset quality and operational performance. We hope it will shed light on the better banking industry in Indonesia.

The structure of this paper is designed as follows. The second section is literature review and hypothesis development. We will discuss on methodology in the third section and present research results and discussion on the fourth section. The last part is the conclusion of the findings including the suggestion for future research agenda.

\section{LITERATURE REVIEW AND HYPOTHESIS DEVELOPMENT}

Examining the bank performance is one of the attractive topics in finance due to the important role of the bank in economics development. The recent study noted that that non-performing loan (NPL) and operational expense ratio(BOPO)are two crucial variables in explaining the bank performance in Indonesia (Chou \& Buchdadi, 2016). Meanwhile, the study exploring the impact of GCG on bank performance in Kenya indicates that better corporate governance leads to better firm performance(Mangunyi, 2011). In addition, one study mentioned globally diversified firms with higher quality corporate governance perform better and are traded at higher values. The quality of GCG implementation variables is measured by the board of directors quality, audit committee quality, and compensation committee quality (Salama and Putnam, 2013). Trying to modified both findings, in this study we will examine the impact of GCG variables on NPL and BOPO. Asset quality of the bank is measured by NPL. This variable also commonly used to measured bank efficiency. Bad management of the bank affects the process of granting loans that might lead to higher NPL (Arafat et al., 2013). While operation expense ratio is also a measurement of banking efficiency. The lower the ratio of operating expenses to total assets, the more efficient a financial institution is (Staikouras, Mamatzakis and Koutsomanoli-Filippaki, 2008). So, in this study the firm performance used acutally a measurement of banking efficiency. In addition, we also used the asset as the control variabel which is commonly employed in corporate governance research (Tao and Hutchinson, 2013)

\subsection{Effects of Independent Board of Directors on Asset Quality and Operational Performance}

The independent director will have a better monitoring role in the firm. They will bring their connection and expertise to make the firm have the better achievement(Mashayekhi and Bazaz, 2008; Al-Najjar, 2014; Müller, 2014; Duru, Iyengar and Zampelli, 2015). In addition, We noted that board independence and number board meeting variables are positive significant to the bank performance(Liang, Xu and Jiraporn, 2013; Liu et al., 2015; Zhu et al., 2016; Chou and Buchdadi, 2017)For examining the impact of the independent board, we modified the variable definition used by Duru et al. (2015). Despite we use the proportion of independent board for measuring the independent board variable, we use the natural logarithmic of the independent board as it used in Duru et al. (2015) for measuring board size. The reason for modifying this variable is regarding the regulation that the proportion of independent board for the bank is at least 50\% (Indonesia, 2006). Then, we got the variability of this proportion is relative not high. So, we prefer to use the number of the independent board which has more variability among the bank.

Even though we found one study (Cavaco et al., 2017) argue independent board is negatively correlated with operating performance; we propose the positive association regarding the board of directors in banking have to pass fit and proffer test conduct by the central bank. Then, the board of directors will have the skills and knowledge needed in the banking industry. Considering these results, we posit the first hypotheses as follow:

H1: Board independence will negativelyassociated with NPL

$\mathrm{H} 2$ : Board independence will negativelyassociated with BOPO 


\subsection{Effect of Board of Directors Meeting on Asset Quality and Operational performance}

One of the easiest ways to evaluate the board performance is counted their attendance at the board meeting. The more meeting they have, the more intense they do their role in monitoring and advice the firm. Bank Indonesia regulation use the attendance record as the proxy that the board member has adequate time to play the role of the board of director (Indonesia, 2006). In addition, from the previous research we noted from Chou, Chung, and Yin (2013) that board meeting has a positive impact on the firm performance. However, it is mentioned that the board should be at the meeting by themselves not by the representative.

Chou, Chung, and Yin (2013) examine the board meeting variable by using two proxies. The first proxy is the percentage of board meetings attended by a director him/herself and the second is the percentage of board meetings attended by representatives authorized by a director. Meanwhile, the regulation of Bank Indonesia stated that at least the board of director makes 4 (four) meetings annually which at least 2 (two) times attended by the whole member of the board of directors (Indonesia, 2006). From the annual report of the bank, we noted there is three information of board meeting on it. The first is the number of meeting internally of the board of director. The second is the number of meeting board of director with a board of executive. The last is the attendance level of both kind meeting mentioned before. Then, in this study we propose two proxies for these two kinds of board meetings. Inspired from Chou, Chung, and Yin (2013), we use the percentage of board attendance of internal board and board-executive meeting. Regarding the results of previous studies, we posit the hyphotheses as folow:

H3: Board of directors meeting variable will negativelyassociated with NPL.

$\mathrm{H} 4$ : Board of directors meeting variable will negativelyassociated with BOPO.

H5: Board of directors-Executive meeting variable will negativelyassociated with bank performance NPL.

H6: Board of directors-Executive meeting variable will negativelyassociated with BOPO.

H7: The percentage attendance of board of directors meeting variable will negativelyassociated with NPL.

H8: The percentage attendance of board of directors meeting variable will negativelyassociated with BOPO.

H9: The percentage attendance of board of directors-Executive meeting variable will negativelyassociated with NPL.

H10: The percentage attendance of board of directors-Executive meeting variable will negativelyassociated with BOPO.

\subsection{Effect of Committee on Asset Quality and Operational Performance}

According to the bank Indonesia regulation, board of directors of the bank have to organize at least 3 committees, i.e. audit committee, risk monitoring committee, and remuneration and nomination committee (Indonesia, 2006). Both audit committee and risk monitoring committee have to build by hiring independent member that has no relationship to the bank. We noted some research examining the committee under the board of director body such as Tao and Hutchinson (2013) found that the composition of the risk and compensation committees is positively associated with risk, which, in turn, is associated with firm performance. Meanwhile, Salim; Arjomandi; and Seufert (2016) found that committee meetings have robustly significant and positive effects on efficiency. In addition, Munisi and Randoy (2013) mentioned that for publicly listed companies across Sub-Saharan African countries the audit committee sub-indices are associated positively and significantly with accounting performance. However, the audit committee sub-indices are associated negatively and significantly with market valuation. In this study, the audit committee sub-indices are including the independence of committee and reporting of the committee meeting. So, in this study we will examine the impact to firm performance similar way as board of directors meeting variable. Tao and Hutchinson (2013) used committee characteristic (size, the proportion of independent member, experience, and activity) for this variable. Meanwhile, Salim; Arjomandi; and Seufert (2016) used committee meeting for explaining the bank efficiency. So, we will use 3 (three) proxies for these three committee bodies. The first is a number of committee member, the second is the number of annual committee meetings, and the last is the percentage of committee meeting attendance. Then, the hypothesis build in this model are:

H11: The number of audit committee member will negatively associated with NPL.

H12: The number of audit committee member will negatively associated with BOPO.

H13:The number of annual audit committee meeting will negatively associated with NPL.

H14:The number of annual audit committee meeting will negatively associated with BOPO.

H15:The percentage of attendance of annual audit committee meeting will negatively associated with NPL.

$\mathrm{H16}$ :The percentage of attendance of annual audit committee meeting will negatively associated with BOPO.

H17: The number of risk committee member will negatively associated with NPL.

H18: The number of risk committee member will negatively associatedBOPO.

H19:The number of annual risk committee meeting will negatively associated with NPL. 
H20:The number of annual risk committee meeting will negatively associated with BOPO.

H21:The percentage of attendance of annual risk committee meeting will negatively associated with NPL.

$\mathrm{H} 22$ :The percentage of attendance of annual risk committee meeting will negatively associated with BOPO.

\section{METHODOLOGY}

The data are obtained from the annual report of listed bank in Indonesia Capital Market during 2013 - 2015.

We build the equation models using two stage least squares (2SLS) method. Some research mentioned that the endogenity problems could be solved by applying this model (Schultz, Tan and Walsh, 2010; Al-Najjar, 2014) .

The equation models for this study are:

Performance $_{i, t}=\quad \alpha+\beta_{1} \cdot$ LNAsset $_{i, t}+\beta_{2} \cdot$ GCGVariables $_{i, t}+\varepsilon_{i, t}$ Where $\mathrm{i}$ indexes the bank, and $\mathrm{t}$ indexes the year (2013-2105). Performance is measured by non- performing loan (NPL) and operational expense ratio (BOPO).

\section{RESEARCH RESULTS AND DISCUSSION}

\subsection{Descriptive Statistics}

The results of descriptive statistic test on table 1 reveal that the samples have a big span of asset value as shown that asset average is IDR 108.891.306, 31 million with the standar deviation IDR 202,045,567.40 million. The biggest bank has IDR 910.063.409 million on asset value, while the smallest bank only has IDR 745,647 million on asset value. Furthermore, the samples on average have good non-performing loan ratio (NPL) and operating expense ratio (BOPO). The value of average NPL is $2.2 \% 1$ which is lower than $5 \%$, the standard value of good bank according to central bank regulation. The value of average BOPO is $86.01 \%$ that is also better the criterion released by thecentral bank reference (lower than $88.5 \%$ ) (Direktorat Kredit, BPR, 2011).

Table 1: Descriptive Statistic

\begin{tabular}{lllllll}
\hline & N & Mean & Median & Stdev & Min & Max \\
\hline Asset (million IDR) & 114 & $108,891,306.31$ & $21,021,634.50$ & $202,045,567.40$ & $745,647.00$ & $910,063,409.00$ \\
NPL & 114 & $2.21 \%$ & $1.94 \%$ & $2.05 \%$ & $0.00 \%$ & $12.28 \%$ \\
BOPO & 114 & $86.01 \%$ & $87.83 \%$ & $17.76 \%$ & $9.27 \%$ & $173.80 \%$ \\
IB & 107 & 2.72 & 3.00 & 0.86 & 1.00 & 5.00 \\
BM & 94 & 14.28 & 8.00 & 14.60 & 3.00 & 64.00 \\
BEM & 70 & 12.01 & 12.00 & 7.87 & 2.00 & 38.00 \\
\%BMAtt & 88 & $86.98 \%$ & $91.83 \%$ & $14.35 \%$ & $50.00 \%$ & $100.00 \%$ \\
\%BEMAtt & 62 & $84.98 \%$ & $89.00 \%$ & $14.40 \%$ & $39.29 \%$ & $100.00 \%$ \\
AC & 108 & 3.91 & 4.00 & 1.10 & 3.00 & 8.00 \\
ACM & 105 & 12.57 & 11.00 & 8.41 & 2.00 & 43.00 \\
\%ACMAtt & 93 & $89.62 \%$ & $92.65 \%$ & $12.83 \%$ & $44.52 \%$ & $100.00 \%$ \\
RC & 106 & 4.21 & 4.00 & 1.39 & 2.00 & 8.00 \\
RCM & 103 & 9.49 & 7.00 & 6.78 & 2.00 & 35.00 \\
\%RCMAtt & 92 & $89.21 \%$ & $93.32 \%$ & $12.51 \%$ & $45.70 \%$ & $100.00 \%$ \\
\hline Asset in IDR million, We do & not have the & & & & \\
\hline
\end{tabular}

Asset in IDR million, We do not have the balance number of data regarding not all information is provided in the annual report.

In addition, the regulation of central bank noted that the independent board of direcors hired should be at least $50 \%$ of the board of directors member. Moreover, the bank has to hire at least 3 people as the board of directors(Sentral, 2013). We can note from table 1 that on average the number of independen board of direcors is around 3 which around $46.7 \%$ banks have two independent directors and $51.4 \%$ has more than 2 peopleindependent board of directors. Furhermore, in accordance with the central bank regulation the board of directors has to make 4 (four) annual meetings that at least 2 (two) times attended by the whole member of the board of directors. Then, we can note from table 1 that listed bank in Indonesia obey the regulation of the central bank which the banks have around 14 times annual meeting with the attendance level more than $80 \%$. Furthermore, the regulation of bank central regarding the committe member it is noted that at least one independent board of director and one independent professional join in audit committee and risk 
committee. The proportion of independent personel should be more than $50 \%$. The regulation does not mention the minimal annual meeting should be conducted as it will depend on the need of each bank. Yet, The meeting could be held whether more than $50 \%$ members attend the meeting include one independent board and an independent party(Sentral, 2013). The result of descriptive test table 1 reveals that the audit committee member is around four persons with average annual meeting 12 times and the attendance level $89 \%$ annually. While the risk committee member is around four persons with average annual meeting 9 times and the attendance level $89 \%$ annually. Furthermore, we conducted some preliminary test of the data multicollinearity test, test for normality, heteroscedasticity test, autocorrelation test, Chow test, and Housman test. We conclude that there is no multicollinearity among the independent variables as it shown in table 2 all the absolut value of Pearson's correllation are less than 0.9 .

Table 2: Multicollinearity Test Results

\begin{tabular}{|c|c|c|c|c|c|c|c|c|c|c|c|}
\hline & IB & $B M$ & $\%$ BM Att & BEM & $\%$ BEM Att & $A C$ & $A C M$ & $\%$ ACM Att & $R C$ & $R C M$ & $\%$ RCM Att \\
\hline IB & 1,000 & & & & & & & & & & \\
\hline$B M$ & 0,438 & 1,000 & & & & & & & & & \\
\hline$\%$ BM Att & $-0,353$ & $-0,372$ & 1,000 & & & & & & & & \\
\hline BEM & 0,217 & 0,519 & $-0,473$ & 1,000 & & & & & & & \\
\hline$\%$ BEM Att & $-0,108$ & $-0,104$ & 0,644 & $-0,267$ & 1,000 & & & & & & \\
\hline$A C$ & 0,432 & 0,353 & $-0,216$ & 0,297 & 0,013 & 1,000 & & & & & \\
\hline$A C M$ & 0,449 & 0,413 & $-0,356$ & 0,363 & $-0,221$ & 0,139 & 1,000 & & & & \\
\hline$\%$ ACM Att & $-0,139$ & $-0,107$ & 0,341 & $-0,398$ & 0,426 & $-0,318$ & $-0,261$ & 1,000 & & & \\
\hline$R C$ & 0,535 & 0,100 & $-0,043$ & 0,017 & 0,194 & 0,649 & 0,142 & $-0,127$ & 1,000 & & \\
\hline$R C M$ & 0,379 & 0,572 & $-0,487$ & 0,494 & $-0,394$ & 0,206 & 0,671 & $-0,202$ & 0,002 & 1,000 & \\
\hline$\%$ RCM Att & $-0,225$ & $-0,112$ & 0,279 & $-0,411$ & 0,290 & $-0,240$ & $-0,165$ & 0,618 & $-0,193$ & $-0,133$ & 1,000 \\
\hline
\end{tabular}

\subsection{Discussion}

We provide the results of a regressionin table 3. From the first model, we noted that the independent board of directors have a negatif impact to the NPL. The more independent board of directors hired, the lower NPL on the bank portfolio. It means the argument that the outsider board of directors will bring the skill, knowledge, networking, and expertise to make better business is valid for the bank in Indonesia (Mashayekhi and Bazaz, 2008; Al-Najjar, 2014; Müller, 2014; Zhu et al., 2016). It is reasonable as the regulation in Indonesia noted that an independent board of director have to pass the fit and proper test by the Financial Service Autorithy (OJK). The test aims to guarantee the board of director have integrity, good reputation, and competency in all aspect of the banking business.

Furthermore, the findings also reveal the board of director meeting and also the attendance level of the member has a good impact on operational performance. Both of variables will reduce the operational cost. Liang et al. (2013) mentioned that the frequency of meeting is an indication of the proactive board of directors. They supervise and do the advisory role to the top management regularly and hopefully make the better performance. This study aligns with the result of liang et al. on the relationship between board meeting and expense. While the result that board meeting will improve the quality of asset (measured by NPL) is statistically not significant. Moreover, this study also supports the argument that board of director meeting will have a positive impact whether the meeting is attended by the board of directors by themselves (Chou, Chung and Yin, 2013).

In model 3 and model 4 , we try to examine the impact of the audit committee and risk committee to bank performance. The results reveal the important role of the audit committee. The audit committee variable will improve the operating perfrmance, and the audit committee meeting will enhance the asset quality. These results broaden the previous research that mentioned audit committee have a positive impact on accounting based performance (Munisi and Randoy, 2013). Yet, this study could not found the significant relationship of risk committee to the performance. Regarding the value of $F$ test of model 3 and model 4 , it needs further research to confirm these findings. Probably, the future research could use longer window period as well as the number of the bank.

Table 3: Regression Result

\begin{tabular}{|c|c|c|c|c|c|}
\hline Variable & NPL & BOPO & Variable & NPL & BOPO \\
\hline Model & Fixed & Fixed & Model & Random & Random \\
\hline $\mathrm{N}$ & 53 & 53 & $\mathrm{~N}$ & 92 & 92 \\
\hline Constant & -0.168 & -0.534 & Constant & 0.067 & 1.515 \\
\hline & 0.018 & 0.093 & & -0.002 & -0.036 \\
\hline LN ASSET & (0.915) & (1.006) & LN ASSET & $(-0.788)$ & $\begin{array}{l}(- \\
2.395)^{* *}\end{array}$ \\
\hline LN IB & $\begin{array}{l}-0.046 \\
(- \\
3.262)^{* * *}\end{array}$ & $\begin{array}{l}0.085 \\
(1.284)\end{array}$ & LN AC & $\begin{array}{l}-0.030 \\
(-0.237)\end{array}$ & $\begin{array}{l}-0.139 \\
(- \\
2.538)^{* *}\end{array}$ \\
\hline
\end{tabular}




\begin{tabular}{|c|c|c|c|c|c|}
\hline LN BM & $\begin{array}{l}-0.014 \\
(-1.675)\end{array}$ & $\begin{array}{l}-0.088 \\
(-2.240) * *\end{array}$ & LN ACM & $\begin{array}{l}0.001 \\
(0.205)\end{array}$ & $\begin{array}{l}0.000 \\
(0.006)\end{array}$ \\
\hline LN BEM & $\begin{array}{l}-0.003 \\
(-0.209)\end{array}$ & $\begin{array}{l}0.026 \\
(0.426)\end{array}$ & \% ACM Att. & $\begin{array}{l}-0.042 \\
(-2.321)^{* *}\end{array}$ & $\begin{array}{l}-0.063 \\
(-0.671)\end{array}$ \\
\hline$\%$ BM Att & $\begin{array}{l}-0.031 \\
(-1.008)\end{array}$ & $\begin{array}{l}-0.300 \\
(-2.066)^{*}\end{array}$ & LN RC & $\begin{array}{l}0.008 \\
(0.901)\end{array}$ & $\begin{array}{l}0.053 \\
(1.214)\end{array}$ \\
\hline \multirow[t]{2}{*}{ \% BEM Att } & $\begin{array}{l}-0.009 \\
(-0.228)\end{array}$ & $\begin{array}{l}0.132 \\
(0.720)\end{array}$ & LN RCM & $\begin{array}{l}0.005 \\
(1.115)\end{array}$ & $\begin{array}{l}0.034 \\
(1.338)\end{array}$ \\
\hline & & & $\%$ RCM Att & $\begin{array}{l}0.003 \\
(0.232)\end{array}$ & $\begin{array}{l}0.085 \\
(1.052)\end{array}$ \\
\hline$R^{2}$ & 0.917 & 0.971 & $R^{2}$ & 0.095 & 0.148 \\
\hline Adj. $R^{2}$ & 0.747 & 0.911 & Adj. $R^{2}$ & 0.002 & 0.077 \\
\hline$F$ & $5.399 * * *$ & $16.388^{* * *}$ & $\mathrm{~F}$ & 1.269 & $2.096 *$ \\
\hline Normality Test & $39.948 * * *$ & $100.188^{* * *}$ & Normality Test & $430.840 * * *$ & 618.542 \\
\hline $\begin{array}{l}\text { Autocorrellation } \\
\text { Test }\end{array}$ & 3.045 & 0.000 & $\begin{array}{l}\text { Autocorrellation } \\
\text { Test }\end{array}$ & 2.559 & 0.781 \\
\hline $\begin{array}{l}\text { Heteroscedasticsity } \\
\text { Test }\end{array}$ & $11.702^{*}$ & 4.866 & $\begin{array}{l}\text { Heteroscedasticsity } \\
\text { Test }\end{array}$ & 9.752 & 7.433 \\
\hline
\end{tabular}

$* * *, * *, *=$ significance at the $1 \%, 5 \%$, and $10 \%$ respectively. Non-performing Loan (NPL) is the ammount money of loan that is in default or clse to default. Operational expense ratio (BOPO) is a ratio between operational expense and operational revenue. LNASSET is the natural logarithmic of Total Asset. LNIB is the natural logarithmic of independent board member in the board of directors body. LNBM is the natural logarithmic of the number of board of directors annual meeting. LNBEM is the natural logarithmic of the number of annual meeting among the board of directors and executives. \%BM Att is the percentage of board meeting attended by the board of directors. \% BEM Att is the percentage of board and executives meeting attended by the board of directors. LNAC is the natural logarithmic of the number of audit Committee member. LNACM is the natural logarithmic of the number of the annual meeting of audit Committee. \% ACM Att is the percentage of audit committee meeting attended by the member of risk committee. LNRC is the natural logarithmic of the number of Risk Committee member. LNRCM is the natural logarithmic of the number of the annual meeting of Risk Committee. \% RCM Att is the percentage of RiskCommittee meeting attended by the member of risk committee Jargue-Berra test for examining the normality distibution of the residual. The results show that not all the model has normality distribution. Then, we assume that whether the data point is greater than 30 , then the data would approximately follow normally distribution.

\section{CONCLUSIONS}

This study discuss about the impact of independent board of directors, board meeting, audit committee, and risk committee on bank practise in Indonesia. The findings reveal that independent board will improve the prudence principal of the bank. While the board of directors meeting will enhance the operational performance of the bank. Regarding these results, the central bank and also the other stakeholders could maintain the role of independent board of directors as well as the number of high quality annual meeting of the board. In addition, this study also reveals the role of audit committee in banking business. The number of audit committee will make better operational performance, while the number of meeting will improve the non-performing loan. This study supports the agency theory that monitoring activity will make the firm better performance.Yet, this study does not provide a positive impact from risk committee. We encourage further research to complement these findings to confirm and make a comprehensive findings about the role of board independence, board meeting, and committee in banking industry, especially from the perspective of developing country.

\section{ACKNOWLEDGEMENTS}

The second author is a faculty of Economics, State University of Jakarta, Indonesia and also a recipient student in STUST Taiwan on the 3+1 Indonesian Directorate General of Higher Education (Dikti) and Elite Study in Taiwan (ESIT) Scholarship Fellowship. 


\section{REFERENCES}

Abdallah, A. A.-N. and Ismail, A. K. (2016) 'Corporate Governance Practices, Ownership Structure, and Corporate Performance in the GCC Countries', Journal of International Financial Markets, Institutions and Money. Elsevier B.V., In Press(In Press), p. In Press. doi: 10.1016/j.intfin.2016.08.004

Akbar, S., Poletti-Hughes, J., El-Faitouri, R. and Shah, S. Z. A. (2016) 'More on the relationship between corporate governance and firm performance in the UK: Evidence from the application of generalized method of moments estimation', Research in International Business and Finance. Elsevier B.V., 38, pp. 417-429. doi: 10.1016/j.ribaf.2016.03.009.

Al-Najjar, B. (2014) 'Corporate governance, tourism growth and firm performance: Evidence from publicly listed tourism firms in five Middle Eastern countries', Tourism Management. Elsevier Ltd, 42, pp. 342-351. doi: 10.1016/j.tourman.2013.09.008.

Arafat, M. Y., Warokka, A., Buchdadi, A. D. and Suherman (2013) 'Banking efficiency and performance: a test of banking characteristics in an emerging market', J. for Global Business Advancement, 6(1), pp. 13-23. doi: 10.1504/JGBA.2013.053475.

Ararat, M., Black, B. S. and Yurtoglu, B. B. (2016) 'The Effect of Corporate Governance on Firm Value and Profitability: Time-Series Evidence from Turkey', Emerging Markets Review. Elsevier B.V., 30(August 2013), pp. 113-132. doi: 10.1016/j.ememar.2016.10.001.

Balachandran, B. and Faff, R. (2015) 'Corporate governance, firm value and risk: Past, present, and future', Pacific-Basin Finance Journal. Elsevier B.V., 35, pp. 1-12. doi: 10.1016/j.pacfin.2015.07.002.

Cavaco, S., Crifo, P., Rebérioux, A. and Roudaut, G. (2017) 'Independent directors: Less informed but better selected than affiliated board members?', Journal of Corporate Finance. Elsevier B.V. doi: 10.1016/j.jcorpfin.2017.01.004.

Chauhan, Y., Lakshmi, K. R. and Dey, D. K. (2016) 'Corporate governance practices, self-dealings, and firm performance: evidence from india', Journal of Contemporary Accounting \& Economics. Elsevier Ltd, 12(3), pp. 274-289. doi: 10.1016/j.jcae.2016.10.002.

Chou, H. I., Chung, H. and Yin, X. (2013) 'Attendance of board meetings and company performance: Evidence from Taiwan', Journal of Banking and Finance. Elsevier B.V., 37(11), pp. 4157-4171. doi: 10.1016/j.jbankfin.2013.07.028.

Chou, T.-K. and Buchdadi, A. D. (2017) 'Independent Board, Audit Committee, Risk Committee, the Meeting Attendance level and Its Impact on the Performance: A Study of Listed Banks in Indonesia', International Journal of Business Administration, 8(3), p. 24. doi: 10.5430/ijba.v8n3p24.

Chou, T. K., and Buchdadi, A. D. (2016) 'Bank Performance and Its Underlying Factors: A Study of Rural Banks in Indonesia', Accounting and Finance Research, 5(3), pp. 55-63. doi: 10.5430/afr.v5n3p55.

Claessens, S. and Yurtoglu, B. B. (2013) 'Corporate governance in emerging markets: A survey,' Emerging Markets Review. Elsevier B.V., 15, pp. 1-33. doi: 10.1016/j.ememar.2012.03.002.

Direktorat Kredit, BPR, dan U. (2011) Model Bisnis Bank Perkreditan Rakyat (Referensi mengelolaBPR) (BPR's business model (reference for managing BPR), Bank Indonesia. Available at: http://www.bi.go.id/id/publikasi/lain/lainnya/Pages/ModelBisnisBPR.aspx (Accessed: 10 April 2017).

Duru, A., lyengar, R. J. and Zampelli, E. M. (2015) 'The dynamic relationship between CEO duality and firm performance: The moderating role of board independence,' Journal of Business Research. Elsevier Inc., 69(10), pp. 4269-4277. doi: 10.1016/j.jbusres.2016.04.001.

Hamidah, Purwati, E. S. and Mardiyati, U. (2013) ‘Pengaruh Corporate Governance Dan Leverage Terhadap Profitabilitas Bank Yang Go Public Di Indonesia (The impact of corporate goveernance and leverage ratio to bank profitability which listed in Indonesia during 20092012 period)', Jurnal Riset Manajemen Sains Indonesia (JRMSI), 4(2), pp. 276-296.

Indonesia, B. (2006) Peraturan Bank Indonesia Nomor 8/4/PBI/2006 Tentang Pelaksanaan Good Corporate Governance Bagi Bank Umum (Bank Indonesia Regulation No. 8/4 / PBI / 2006 on Implementation of Good Corporate Governance for Commercial Bank). Available at: http://www.bi.go.id/id/peraturan/kodifikasi/bank/Documents/GCG Complete.pdf.

Liang, Q., Xu, P. and Jiraporn, P. (2013) 'Board characteristics and Chinese bank performance', Journal of Banking and Finance. Elsevier B.V., 37(8), pp. 2953-2968. doi: 10.1016/j.jbankfin.2013.04.018.

Liu, Y., Miletkov, M. K., Wei, Z. and Yang, T. (2015) 'Board independence and firm performance in China', Journal of Corporate Finance. Elsevier B.V., 30, pp. 223-244. doi: 10.1016/j.jcorpfin.2014.12.004.

Mangunyi, E. E. (2011) 'Ownership Structure and Corporate Governance and Its Effects on Performance: A Case of Selected Banks in Kenya', International Journal of Business Administration, 2(3), pp. 2-18. doi: 10.5430/ijba.v2n3p2.

Markonah, Cahaya, Y. F. and Riwayati, H. E. (2016) 'The Effect of Banking Company Performance toward Good Corporate Governance Listed in Indonesia Stock Exchange', Procedia - Social and Behavioral Sciences, 219, pp. 486-492. doi: 10.1016/j.sbspro.2016.05.024.

Mashayekhi, B. and Bazaz, M. S. (2008) 'Corporate Governance and Firm Performance in Iran', Journal of Contemporary Accounting \& Economics. Elsevier Ltd, 4(2), pp. 156-172. doi: 10.1016/S1815-5669(10)70033-3.

Mulili, B. M. and Wong, P. (2011) 'Corporate Governance Practices in Developing Countries: The Case for Kenya', International Journal of Business Administration, 2(1), p. 14. doi: 10.5430/ijba.v2n1p14.

Müller, V.-O. (2014) 'The Impact of Board Composition on the Financial Performance of FTSE100 Constituents', Procedia-Social and 
Behavioral Sciences. Elsevier B.V., 109, pp. 969-975. doi: 10.1016/j.sbspro.2013.12.573.

Munisi, G. and Randoy, T. (2013) 'Corporate Governance and Company Performance across Sub-Saharan African Countries', Journal of Economics and Business. Elsevier Inc., 70, pp. 92-110. doi: 10.1016/j.jeconbus.2013.08.003.

Pradhan, R. P., Arvin, M. B., Hall, J. H. and Bahmani, S. (2014) 'Causal nexus between economic growth, banking sector development, stock market development, and other macroeconomic variables: The case of ASEAN countries', Review of Financial Economics. Elsevier Inc., 23(4), pp. 155-173. doi: 10.1016/j.rfe.2014.07.002.

Prommin, P., Jumreornvong, S., Jiraporn, P. and Tong, S. (2016) 'Liquidity, ownership concentration, corporate governance, and firm value: Evidence from Thailand', Global Finance Journal. Elsevier Inc., 31, pp. 73-87. doi: 10.1016/j.gfj.2016.06.006.

Salama, F. M. and Putnam, K. (2013) 'The impact of corporate governance on the financial outcomes of global diversification', International Journal of Accounting. University of Illinois, 48(3), pp. 364-389. doi: 10.1016/j.intacc.2013.07.003.

Salim, R., Arjomandi, A. and Seufert, J. H. (2016) 'Does corporate governance affect Australian banks' performance?', Journal of International Financial Markets, Institutions and Money. Elsevier B.V., 43, pp. 113-125. doi: 10.1016/j.intfin.2016.04.006.

Schultz, E. L., Tan, D. T. and Walsh, K. D. (2010) 'Endogeneity and the corporate governance - performance relation', Australian Journal of Management, 35(2), pp. 145-163. doi: 10.1177/0312896210370079.

Sentral, P. R. dan E. B. (2013) Manajemen (Good Corporate Governance), Bank Indonesia. Available at: http://www.bi.go.id/web/id/Peraturan/Search (Accessed: 19 December 2016).

Staikouras, C., Mamatzakis, E. and Koutsomanoli-Filippaki, A. (2008) 'An empirical investigation of operating performance in the new European banking landscape', Global Finance Journal, 19(1), pp. 32-45. doi: 10.1016/j.gfj.2008.01.001.

Subramanian, S. (2015) 'Corporate Governance, Institutional Ownership and Firm Performance in Indian State-owned Enterprises', AsiaPacific Journal of Management Research and Innovation , 11(2), pp. 117-127. doi: 10.1177/2319510X15576273.

Tan, Y. (2014) 'Corporate governance in the banking sector', in Performance, Risk and Competition in the Chinese Banking Industry. Elsevier, pp. 39-64. doi: 10.1533/9781780634463.39.

Tao, N. B. and Hutchinson, M. (2013) 'Corporate governance and risk management: The role of risk management and compensation committees', Journal of Contemporary Accounting \& Economics. Elsevier Ltd, 9(1), pp. 83-99. doi: 10.1016/j.jcae.2013.03.003.

Zagorchev, A. and Gao, L. (2015) 'Corporate governance and performance of financial institutions', Journal of Economics and Business, 82, pp. 17-41. doi: 10.1016/j.jeconbus.2015.04.004.

Zhu, J., Ye, K., Tucker, J. W. and Chan, K. (Johnny) C. (2016) 'Board hierarchy, independent directors, and firm value: Evidence from China', Journal of Corporate Finance. Elsevier B.V., 41, pp. 262-279. doi: 10.1016/j.jcorpfin.2016.09.009. 